\title{
Determining the most appropriate feeding regime for the South African abalone Haliotis midae Linnaeus grown on kelp
}

Tamson L. Francis ${ }^{1}$, Gavin W. Maneveldt*1 and Jonathan Venter ${ }^{2}$

1 Department of Biodiversity and Conservation Biology, University of the Western Cape, Private Bag X17, Bellville 7535, South Africa

2 Jacobsbaai Sea Products Farm, Private Bag X2, Rhine Road, Jacobsbaai 8050, South Africa

* Corresponding author: gmaneveldt@uwc.ac.za

\section{Abstract}

Beach-cast kelp (the most widely used feed for commercially grown South African abalone) is plentiful during winter months when periodic storms cause kelp to wash ashore. During summer, however, this resource is not always readily available and farmed abalones are often starved for short periods. The aim of this research was to assess how periodic kelp starvation influences growth of the commercially grown abalone, Haliotis midae Linnaeus. Growth of grow-out abalone was monitored on a commercial abalone farm over a period of six months and consisted of 3 treatments with 2 replicates $(n= \pm 250$ abalone per replicate). The treatments were: Control (abalone always given more kelp than what they typically needed); Treatment 1 (abalone fed their weekly ration only once a week); Treatment 2 (abalone fed half their weekly ration every 3 and then 4 days respectively). While the data at first suggest that the control animals outperform the treatment animals, after undergoing an initial adjustment period to the new feeding regime, the treatment animals perform better. Weight gain and feed conversion efficiencies show that the treatment animals perform better overall. The control animals generally required much more feed to produce comparable increases in both length and weight compared to the treatment animals. This study has shown that periodic bouts of starvation is beneficial to Haliotis midae, allowing variable growth spurts when returned to full feed rations.

Keywords: abalone, compensatory growth, feed conversion efficiency, growth, Haliotis midae, kelp, starvation

Introduction 
Abalone (Haliotis spp.) are in considerable demand in the Far East where they are treated as part of traditional cuisine and ceremony (Chen 1989, Sales 1999, Sales and Britz 2001). Consequently, they have been exploited for centuries because of their food value (Barkai and Griffiths 1986). Presently there is an increasing demand for small, cocktail size abalone of 40-70mm shell length in the international market (Jarayabhand and Paphavasit 1996, Najmudeen and Victor 2004).

Worldwide there are approximately 90 species of abalone, of which 15 are harvested commercially (Sales and Janssens 2004). In South Africa only six Haliotid species occur, and of these, Haliotis midae Linnaeus is the only one that is commercially exploited (Cook 1998, Sales and Britz 2001, Evans et al. 2004). Although the South African abalone fishery has existed since 1949, the first attempt to cultivate H. midae was in 1981 (Genade et al. 1988, Sales and Britz 2001, Steinberg 2005). Since then, South Africa has become the largest abalone producer outside Asia (FAO 2004). This emerging market has largely been driven by over-exploitation of the wild abalone stocks by poaching and by high market prices (Cook 1998, Troell et al. 2006).

The growing South African abalone industry depends largely on a steady supply of feed resources, particularly fresh kelp (Troell et al. 2006). Currently more than 7000 tons of fresh kelp fronds are harvested annually in South Africa to feed cultured abalone and this figure is expected to increase as the growing demand for kelp by local abalone farmers also increases (Anderson et al. 2006). During the winter months, beach-cast kelp is plentiful as storms cause kelp to wash ashore. In summer, however, kelp has to be harvested at sea and delivered to the abalone farms (Anderson et al. 2006, Rothman et al. 2006). The amount of kelp delivered to an abalone farm varies from day to day and often there are days where no kelp may be available. This then means that abalone are often starved of food for short periods. Thus far, no research has focused on the effects of periodic kelp starvation on the growth of farmed H. midae. The aim of this research was therefore to determine the most appropriate feeding regime for the South African abalone, H. midae and to assess how periodic starvation influences its growth.

\section{Materials and Methods}

\section{Experimental system}

The research was conducted at the Jacobsbaai Sea Products ( $17^{\circ} 53^{\prime} 12.5^{\prime \prime}$ E, $32^{\circ} 58^{\prime}$ 2.5" S, Western Cape, South Africa) abalone farm. Flow through seawater with a flow rate of $850-1300 \mathrm{~L}^{-\mathrm{h}^{-1}}$ and moderately aerated, was supplied at a temperature of 
$13.8 \pm 0.76^{\circ} \mathrm{C}$ in the holding tanks. The abalone were grown in culture baskets $(80 \mathrm{x}$ $57 \times 25 \mathrm{~cm}$; length, width and depth respectively) subdivided with feeding plates to increase the surface area.

Experimental animals

Grow-out abalone (abalone with a shell length > 20mm) were supplied by the Jacobsbaai Sea Products abalone farm. Since growth of abalone is variable, individuals of similar size and of the same gene pool (spawned May 2002) were used. These animals were subdivided into two replicate baskets of approximately $12.5 \mathrm{~kg}( \pm$ 250 individuals). The initial weight and shell length of the abalone were measured at $46.47 \mathrm{~g} \pm 0.25$ and $64.31 \mathrm{~mm} \pm 0.75$ respectively. Both body weight and shell length were measured monthly.

\section{Daily Feed Consumption}

A pre-investigation feeding trial was initiated two weeks prior to commencement of the study to ascertain the daily feed consumption of grow-out abalone of the size used in the experiment. It was found that $\pm 12.5 \mathrm{~kg}$ of abalone of the weight and length above consumed roughly $500 g$ of kelp per day. This data was used as the basis for the various treatments that followed and a base weight of $550 \mathrm{oger}$ day (realized feed consumption) was established to compensate for variable daily growth between baskets and between individuals within baskets. The pre-investigation feeding trial ran concurrently with the experiment in order to monitor the on-going consumption as abalone grew throughout the experiment; the feed values were then adjusted accordingly.

Treatments

Three treatments (each with two replicates) were tested.

Control: Considered the ideal conditions in which kelp was always available, i.e. always more than the daily "realised feed consumption" (initially $550 \mathrm{Og}+50 \mathrm{~g}$ ) of kelp in the basket. Monitored daily, deteriorating kelp was always removed and fresh kelp topped up with as much as needed to always have $600 \mathrm{~g}$ in the baskets.

Treatment 1: Initially fed 3,85kg (550g x 7) of kelp on day 1 and then again $3,85 \mathrm{~kg}$ of kelp every 7 days later i.e. bulk feeding at 7 day intervals. This assumed that if the abalone consumed more than the daily "realised feed consumption" of 550g, they would at one stage or another have to starve until day eight when the next bulk feeding occurred. 
Treatment 2: This treatment was included to compensate for any feeding routine that might arise from treatment 1. Abalone were initially fed $1.925 \mathrm{~kg}$ [(550g x 7)/2] on day 1 and then again $1.925 \mathrm{~kg}, 3$ and then 4 days later for the duration of the experiment. The 3-, 4-day cycle was maintained throughout this treatment. As half $(1.925 \mathrm{~kg})$ of the weekly "realised feed consumption" amount of kelp was given over 2 different cycles, it was assumed that there would be both periods of sufficient kelp available (i.e. 3-day cycle), as well as periods where the abalone would be slightly starved of kelp (i.e. 4-day cycle).

By month 2 the "realised feed consumption" was increased by $50 \mathrm{~g}$ to $600 \mathrm{~g}$ of kelp as dictated by the separate, on-going pre-investigation experiment. This new value substituted the previous $550 \mathrm{~g}$ values in all the treatments above and quantities were adjusted accordingly. Hereafter, the "realized feed consumption" was kept constant at $600 \mathrm{~g}$ for both treatments 1 and 2 to build in greater starvation periods into the experiment for the latter four months, while that of the control was increased by $50 \mathrm{~g}$ every second month.

\section{Sampling and data collection}

The experiment was conducted over six months. Representative animals were randomly selected from each treatment $(\mathrm{N}=30$ per replicate at $0-3$ months; $\mathrm{N}=4 \mathrm{O}$ per replicate at 4-6 months to compensate for later differential growth). Before all measurements, abalone were blotted dry to remove excess water. Body weight was recorded to the nearest $0.01 \mathrm{~g}$ using an electronic balance. Shell length was measured along the longest axis of the abalone shell to the nearest $0.1 \mathrm{~mm}$ with a vernier callipers.

Daily increment in shell length (DISL) was calculated using the formula of Zhu et al. (2002):

$\operatorname{DISL}(\mu \mathrm{m} /$ day $)=\left[\left(\mathrm{SL}_{\mathrm{t}}-\mathrm{SL}_{\mathrm{i}}\right) / \mathrm{t}\right] \times 1000$

Where $\mathrm{SL}_{\mathrm{t}}=$ the final mean shell length $(\mathrm{mm}), \mathrm{SL}_{\mathrm{i}}=$ the initial mean shell length $(\mathrm{mm})$, and $\mathrm{t}=$ the feeding trial period in days.

Specific growth rate (SGR in \% body weight.day ${ }^{-1}$ ) was calculated using the formula of Britz (1996):

$\mathrm{SGR}=[(\ln (\mathrm{Wf})-\ln (\mathrm{Wi})) / \mathrm{t}] \times 100$

Where $\ln (\mathrm{Wf})=$ the natural $\log$ of the final mean weight of abalone, $\ln (\mathrm{Wi})=$ the natural $\log$ of the initial mean weight of abalone, and $t=$ the feeding trial period in days. 
The Feed Conversion Efficiency (FCE) was calculated for each treatment using the formula of Simpson and Cook (1998):

$\mathrm{FCE}=($ growth $/$ ration $) \times 100$

Where growth $=$ the blotted wet weight $(\mathrm{g})$ gained per day and ration $=$ the blotted wet feed $(\mathrm{g})$ intake.

Statistical analyses

Unless otherwise stated, all graphed data are expressed as means \pm se. Data for all experimental replicates were pooled as no significant differences were found between them. As no adjustment period was allowed before the start of the experiment, the first two months were considered to be the time necessary for the treatment animals to adjust to the new feeding regimes. For this reason, and to monitor the ongoing change over time, the observations were combined as a split plot analysis of variance with treatments (control, treatments 1 and 2) as main plot factors and months as split plot factors (see Little and Hills 1972). For each treatment and basket combination, linear regression functions were fitted on mean abalone weight and length change over the periods 0-2 and 2-6 months. To do this, mean abalone weight and length were adjusted to be equal at the start of each analysis. Results from the linear regression analyses were then subjected to a one-way analysis of variance to compare treatment regression parameters. Differences among treatments were considered statistically significant at $\mathrm{P}<0.05$.

Results

Abalone fed a diet of kelp will typically invest more energy into length, quite often at the expense of weight (Troell et al. 2006). Growth trends in length are therefore often considered more reliable when determining farm management procedures for abalone fed kelp. This considered, the data suggest that the control animals outperform the treatment animals (Fig 1) with a DISL of $38.123 \mu \mathrm{m} /$ day (Table 1). No significant differences $(\mathrm{P}=0.0975)$ were found between treatments 1 and 2 with regards to mean shell length gain for the entire experimental period (Fig 1, Table 1). The performance in length in the control animals, however, comes at the expense of weight (Fig 2) and the control is not the better performing treatment in terms of specific weight gain (SGR values in Table 1).

Table 1. Growth parameters of abalone from the three treatments. Daily increment increase in shell length (DISL - $\mu$ m.day ${ }^{-1}$ ), specific growth rate (SGR - \% body 
weight.day ${ }^{-1}$ ) and feed conversion efficiency (FCE) are provided for the periods o- 6 months (o-6) and 2-6 months (2-6). Means with the same letter are not statistically different.

\begin{tabular}{llll}
\hline Treatment & Control & Treatment 1 & Treatment 2 \\
\hline DISL (o-6) & $38.123^{\mathrm{a}}$ & $33.102^{\mathrm{b}}$ & $30.478^{\mathrm{b}}$ \\
DISL $^{(2-6)}$ & $22.124^{\mathrm{b}}$ & $25.725^{\mathrm{ab}}$ & $27.896^{\mathrm{a}}$ \\
SGR $^{(0-6)}$ & $0.222^{\mathrm{b}}$ & $0.235^{\mathrm{a}}$ & $0.207^{\mathrm{b}}$ \\
SGR $^{(2-6)}$ & $0.112^{\mathrm{b}}$ & $0.136^{\mathrm{a}}$ & $0.130^{\mathrm{ab}}$ \\
FCE $^{(0-6)}$ & $0.020^{\mathrm{b}}$ & $0.025^{\mathrm{a}}$ & $0.022^{\mathrm{ab}}$ \\
FCE $^{(2-6)}$ & $0.010^{\mathrm{b}}$ & $0.015^{\mathrm{a}}$ & $0.014^{\mathrm{a}}$ \\
\hline
\end{tabular}

Figure 1. Abalone growth in shell length.

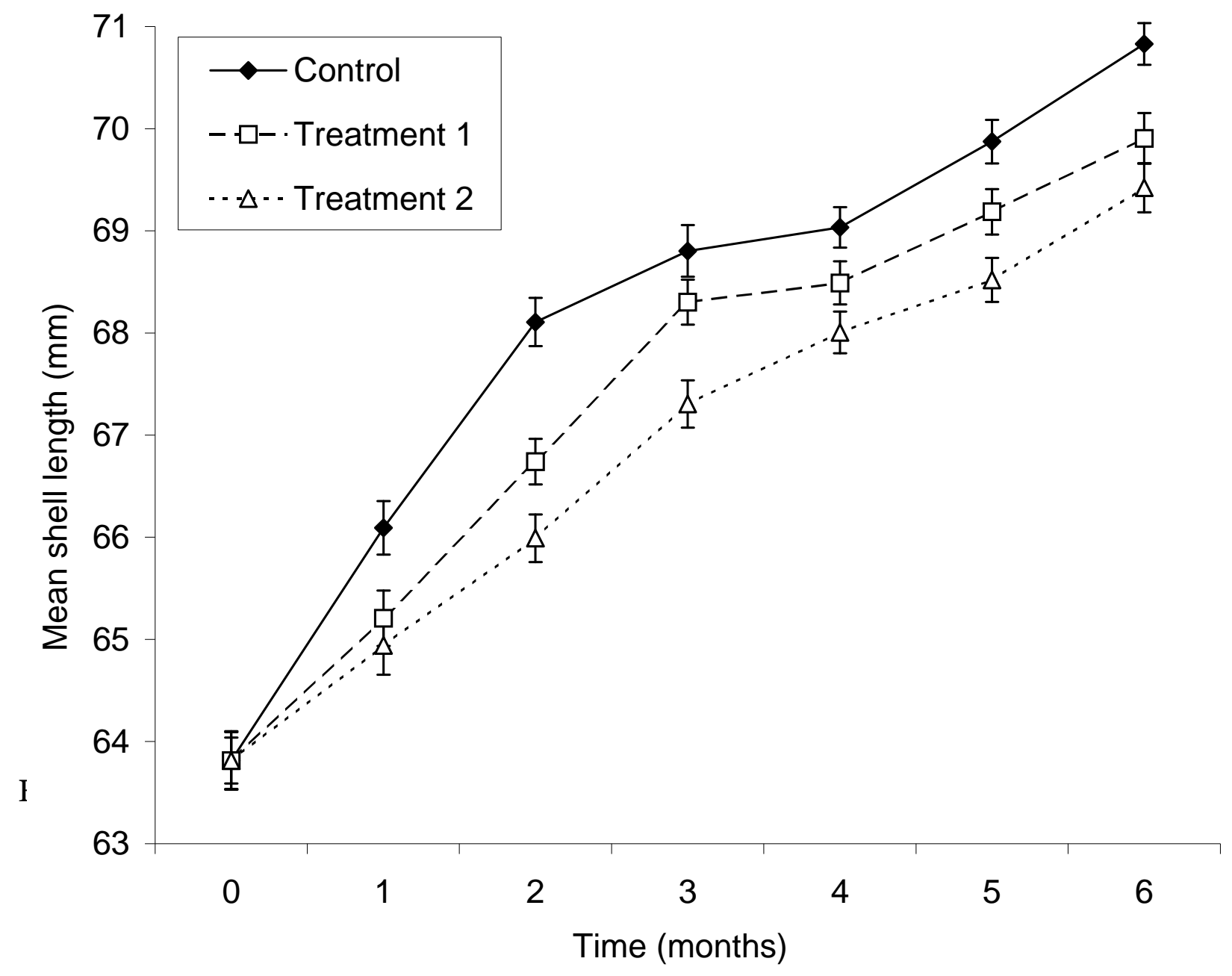




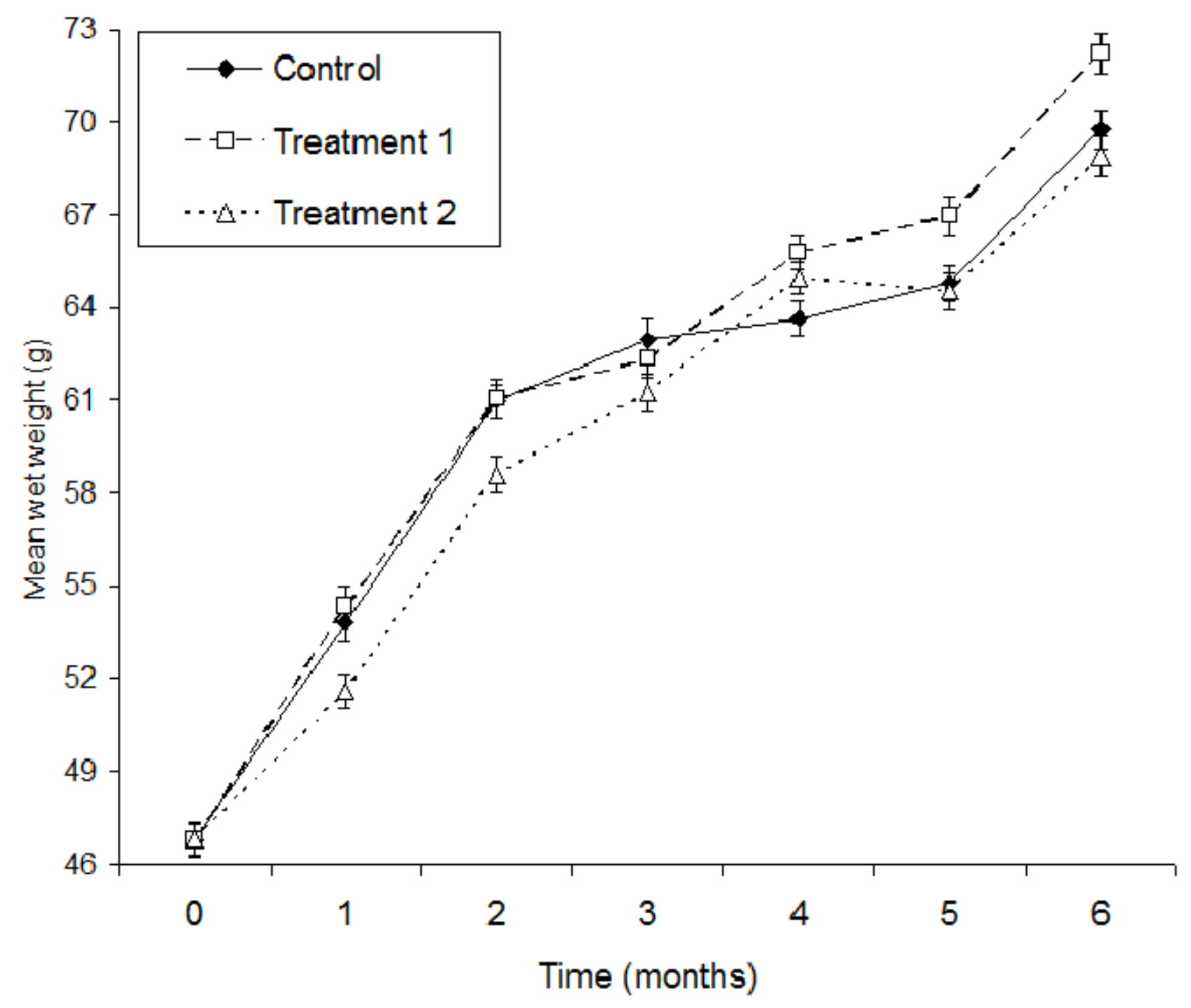

Upon closer examination of the actual rates of growth (visible by the slopes of the graphs) during the latter months (2-6) of the experiment, it is evident that something quite different is happening (see Figs $3 \& 4$, Table 1). The data for the latter 2-6 months show that there are still no significant differences between treatments 1 and 2 for both mean shell length $(\mathrm{P}=0.6046)$ and weight $(\mathrm{P}=0.2063)$; both treatments, however, perform better than the control (Figs 3 \& 4). This is clearly evident from the DISL and SGR values obtained for the period 2-6 months (Table 1). Also, the treatment animals have higher feed conversion efficiencies (FCE) despite the control animals receiving more feed overall. 
Figure 3. Abalone growth in shell length with linear regression functions fitted for the periods $0-2$ and $2-6$ months. Cont $=$ Control; Trt $1=$ Treatment 1 ; Trt $2=$ Treatment 2; B1 = mean for basket $1 ; \mathrm{B} 2=$ mean for basket 2; Predicted $=$ the statistically determined treatment mean determined by the split plot function.

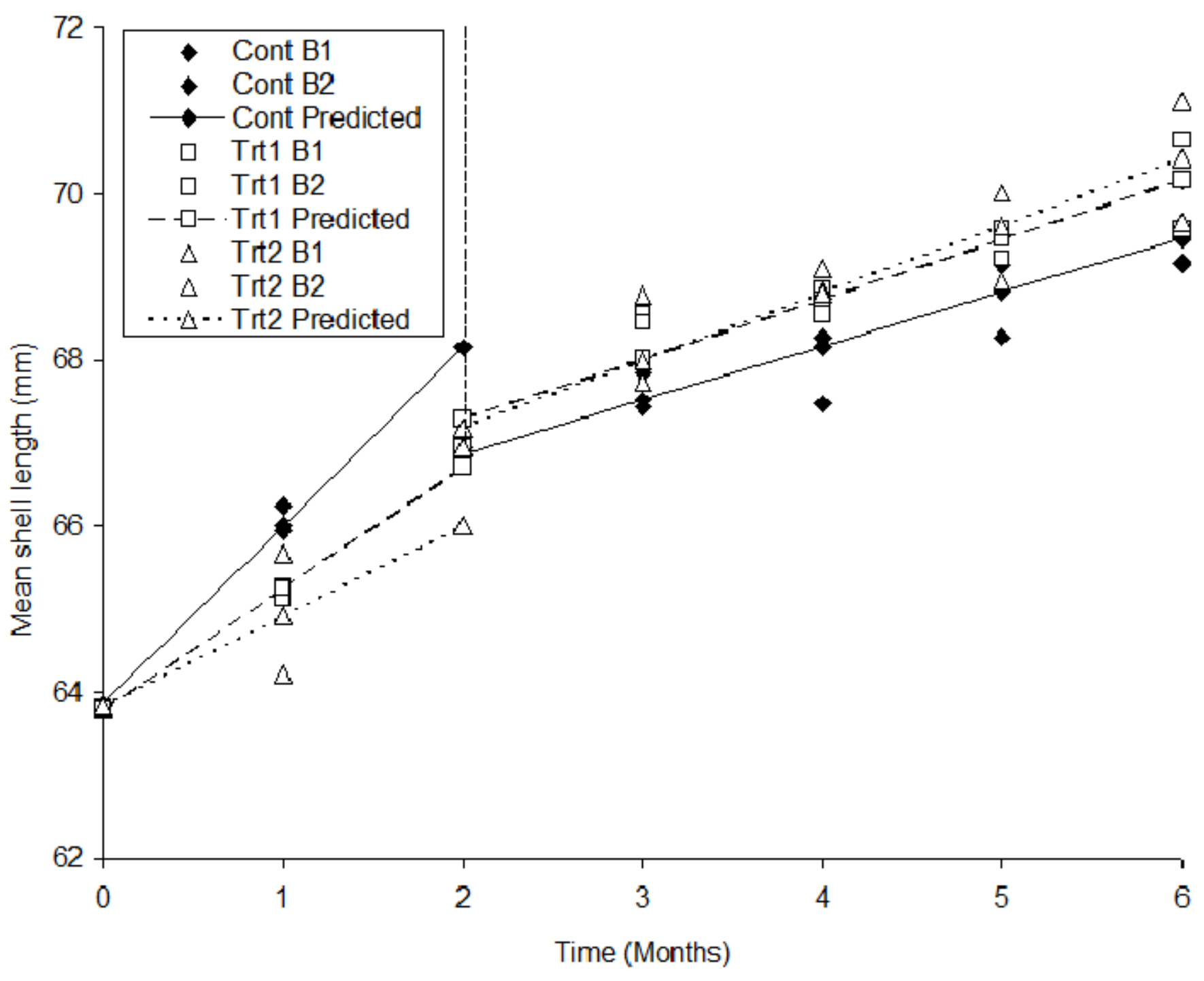


Figure 4. Abalone growth in body weight with linear regression functions fitted for the periods $0-2$ and $2-6$ months. Cont $=$ Control; Trt $1=$ Treatment 1 ; Trt $2=$ Treatment 2; B1 = mean for basket $1 ; \mathrm{B} 2=$ mean for basket 2; Predicted $=$ the statistically determined treatment mean determined by the split plot function.

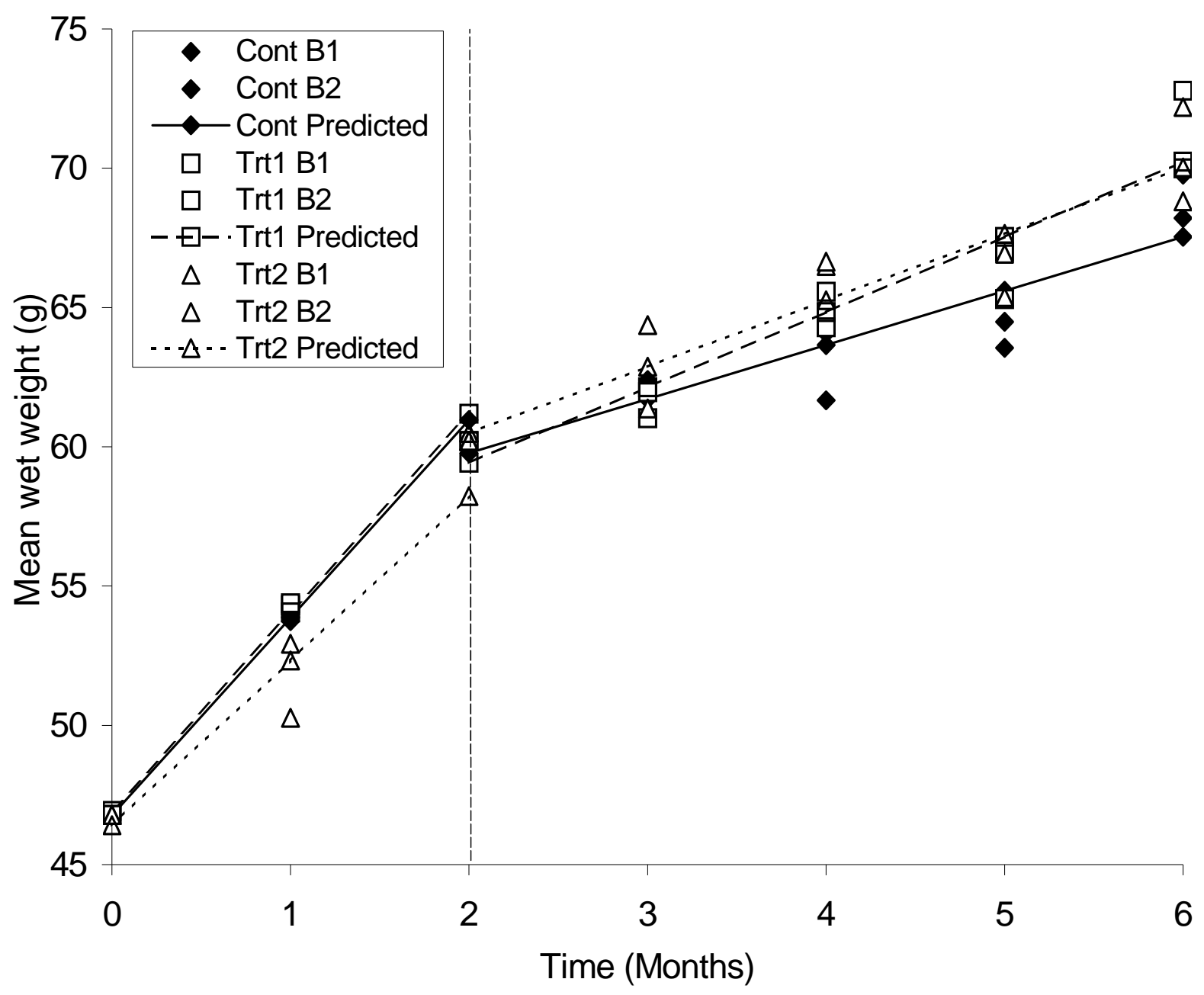

DISL, SGR and FCE values often mean little to the abalone farmer. When the data are re-interpreted into values that the abalone farmer can better understand, we see clearly that the treatment animals perform better than the control animals (Table 2). Despite the control animals gaining more length over the entire experimental period, much more kelp was required to produce an equivalent amount of length in the control animals compared to the treatment animals. In terms of weight gain and the amount of kelp required to produce a net gain in weight, both sets of treatment animals perform better than the control animals. Overall, the treatment animals have higher feed conversion efficiencies that are even more striking for the latter four months (2-6) of the experiment. 
Table 2. Length and weight gained by the animals from the three treatments and the amount of kelp required to produce $1 \mathrm{~mm}$ of shell length and $10 \mathrm{~g}$ of body weight. All data are provided for the periods o-6 months (o-6) and 2-6 months (2-6). Means with the same letter are not statistically different.

\begin{tabular}{|c|c|c|c|}
\hline Treatment & Control & Treatment 1 & Treatment 2 \\
\hline Mean length (mm) gain (o-6) & $7.015^{\mathrm{a}}$ & $6.091^{b}$ & $5.608^{b}$ \\
\hline Mean length (mm) gain (2-6) & $2.721^{b}$ & $3.164^{\mathrm{a}}$ & $3.431^{\mathrm{a}}$ \\
\hline Mean weight (g) gain (o-6) & $22.968 \mathrm{~b}$ & $25.441^{\mathrm{a}}$ & $22.101^{b}$ \\
\hline Mean weight (g) gain (2-6) & $8.775^{b}$ & $11.179^{\text {a }}$ & $10.293^{\mathrm{a}}$ \\
\hline $\begin{array}{l}\text { Mean kelp consumed (g) by } \\
\text { each individual abalone (0-6) }\end{array}$ & $499.214^{\mathrm{a}}$ & $443.8^{b}$ & $443.8^{b}$ \\
\hline $\begin{array}{l}\text { Mean kelp consumed }(g) \text { by } \\
\text { each individual abalone }{ }^{(2-6)}\end{array}$ & $376.614^{\mathrm{a}}$ & $331.8^{b}$ & $331.8^{b}$ \\
\hline $\begin{array}{l}\text { Amount of kelp (g) required } \\
\text { to produce } 1 \mathrm{~mm} \text { shell length } \\
(\mathrm{o}-6)\end{array}$ & $71.168^{b}$ & $72.864^{b}$ & $79.138^{\mathrm{a}}$ \\
\hline $\begin{array}{l}\text { Amount of kelp (g) required } \\
\text { to produce } 1 \mathrm{~mm} \text { shell length } \\
(2-6)\end{array}$ & $138.397^{\mathrm{a}}$ & $104.862^{b}$ & $96.699^{b}$ \\
\hline $\begin{array}{l}\text { Amount of kelp (g) required } \\
\text { to produce } 10 \mathrm{~g} \text { of abalone }(0-6)\end{array}$ & $217 \cdot 348^{a}$ & $174.442^{b}$ & $200.806^{a}$ \\
\hline $\begin{array}{l}\text { Amount of kelp (g) required } \\
\text { to produce } 10 \mathrm{~g} \text { of abalone }(2-6)\end{array}$ & $429.186^{a}$ & $296.802^{b}$ & $322.35^{\mathrm{b}}$ \\
\hline
\end{tabular}

Discussion

While abalone characteristically invest more into shell length than into body weight when fed kelp (because of the high ash and low protein contents - Troell et al. 2006), to the abalone farmer weight gain is more important. This is because revenue is generated on a per-weight-basis. Also, it is generally assumed that providing abalone with more kelp feed than they typically require, will produce optimum growth. This study has, however, shown that periodic bouts of starvation actually benefit the abalone and consequently the abalone farmer as well.

Starvation or restricted feeding is not unusual to marine invertebrates as food periodically becomes scarce or unavailable to them (see e.g. Durazo-Beltrán et al. 2004). It has been documented (e.g. Carefoot et al. 1993, Takami et al. 1995) that abalone can withstand long periods of starvation before body reserves are depleted. This is usually achieved by first metabolising carbohydrates and lipid stores, and then later body proteins (Roberts et al. 2001). Segawa (1991) suggested that carbohydrates and lipids were utilized during normal feeding, and that after about two weeks' starvation, proteins were metabolised as the main energy source. This, 
however, did not apply to the present study as abalone were never starved for periods longer than 1 to 2 days.

In starved molluscs, metabolic rates tend to decrease as starvation progresses (Gaty and Wilson 1986, Carefoot 1987). Many studies (e.g. Quinton and Blake 1990, Jobling and Koskela 1996) have shown that like dietary composition, reproductive state, and unfavourable environments, food restriction or starvation often causes an animal to display compensatory growth. Compensatory growth may be defined as the ability to display a rapid growth spurt when returned to full rations following brief periods of food restriction or starvation (Weatherly and Gill 1981, Miglavs and Jobling 1989, Rueda et al. 1998). Compensatory growth is usually accompanied by hyperphagia (i.e. an increase in food intake - Gurney 2004) and displays itself in improved feed conversion efficiency values (Greef et al. 1986, Miglavs and Jobling 1989). This is clearly evident in the high FCE values obtained by the treatment animals.

In conclusion, once the treatment animals overcame the adjustment period, their presumed slowed metabolism resulted in rapid weight gain through compensatory growth. Periodic kelp starvation is thus not necessarily detrimental to the South African abalone $\mathrm{H}$. midae and may indeed be beneficial as this study has shown, no doubt because of the positive effects of compensatory growth. It should, however, be stressed that were the growth rates not examined so closely, one could so easily have missed the growth spurts evident in the latter months of the experiment. If the experiment were, however, run for a longer period, this trend would have been evident for the full data set. In addition to the main outcome of this research, this study has highlighted the importance of relatively long-term experimentation on relatively slow-growing organisms.

\section{Acknowledgements}

We thank the Department of Biodiversity and Conservation Biology at the University of the Western Cape and the Jacobsbaai Sea Products farm for providing funding, research facilities and technical support. We also thank the South African National Research Foundation (NRF) and the South African Department of Environmental Affairs and Tourism (DEAT) for additional research funding. Deborah RobertsonAndersson and Cliff Jones provided valuable discussion and comments. We thank Max Troell (University of Stockholm, Sweden) and John Bolton (University of Cape Town, South Africa) for the collaboration that made this project a reality. 
References

Anderson RJ, Rothman MD, Share A, Drummond H (2006) Harvesting of the Kelp Ecklonia maxima in South Africa affects its three obligate, red algal epiphytes. Journal of Applied Phycology 18: 343-349.

Barkai R, Griffths C L (1986) Diet of the South African abalone Haliotis midae. South African Journal of Marine Science 4: 37-44.

Britz PJ (1996) The suitability of selected protein sources for inclusion in formulated diets for South African abalone, Haliotis midae. Aquaculture 140: 63-73.

Carefoot TH (1987) Diet and its effect on oxygen uptake in the sea hare Aplysia. Journal of Experimental Marine Biology and Ecology 114: 275-287.

Carefoot TH, Qian P-Y, Taylor BE, West T, Osborne J (1993) Effect of starvation on the energy reserves and metabolism in the Northern abalone, Haliotis kamtschatkana. Aquaculture 118: 315-325.

Chen HC (1989) Farming the small abalone, Haliotis diversicolor supertexta, in Taiwan. In Hahn KO (ed), Handbook of Culture of Abalone and Other Marine Gastropod. CRC Press, Florida, pp. 265-283.

Cook P (1998) The current status of abalone farming in South Africa. Journal of Shellfish Research 3: 601-602.

Durazo-Beltrán E, Viana MT, D’Abramo LR, Toro-Vazquez JF (2004) Effects of starvation and dietary lipid on the lipid and fatty acid composition of muscle tissue of juvenile green abalone (Haliotis fulgens). Aquaculture 238: 329-341.

Evans BS, Sweijd NA, Bowie RCK, Cook PA, Elliott NG (2004) Population genetic structure of the perlemoen Haliotis midae in South Africa: evidence of range expansion and founder events. Marine Ecology Progress Series 270: 163-172.

FAO (2004) The State of the World Fisheries and Aquaculture 2004. Food and Agriculture Organization, Rome, pp 153. 
Gaty G, Wilson JH (1986) Effect of body size, starvation, temperature and oxygen tension on the oxygen consumption of hatchery-reared ormers Haliotis tuberculata L. Aquaculture 56: 229-237.

Genade AB, Hirst AL, Smit CJ (1988) Observations on the spawning, development and rearing of the South African abalone, Haliotis midae Linn. South African Journal of Marine Science 6:3-12.

Greef JC, Messner HH, Roux CZ, Janse Van Rensburg RJ (1986) The effect of compensatory growth on feed intake, growth rate and efficiency of feed utilization in sheep. South African Journal of Animal Science 16: 155-161.

Gurney WS (2004) Resource Allocation, Hyperphagia and Compensatory Growth. Bulletin of Mathematical Biology 66: 1731-1753.

Jarayabhand P and Paphavasit N (1996) A review of the culture of tropical abalone with special reference to Thailand. Aquaculture 140: 159-168.

Jobling $\mathrm{M}$ and Koskela $\mathrm{J}$ (1996) Interindividual variations in feeding and growth in rainbow trout during restricted feeding and in a subsequent period of compensatory growth. Journal of Fish Biology 49: 658-667.

Little TM, Hills FJ (1972) Statistical Methods in Agricultural Research. University of California Davis, Berkeley, California, pp.100.

Miglavs I, Jobling M (1989) Effects of feeding regime on food consumption, growth rates and tissue nucleic acids in juvenile Arctic charr, Salvelinus alpinus, with particular respect to compensatory growth. Journal of Fish Biology 34: 947-957.

Najmudeen TM, Victor AC (2004) Seed production and juvenile rearing of the tropical abalone Haliotis varia Linnaeus 1758. Aquaculture 234 (1-4): 277-292.

Quinton JC, Blake W (1990) The effects of feeding cycling and ration level on the compensatory growth response in rainbow trout, Oncorhynchus mykiss. Journal of Fish Biology 37: 34-41.

Roberts RD, Lapworth C, Barker RJ (2001) Effect of starvation on the growth and survival of post-larval abalone (Haliotis iris). Aquaculture 200: 323-338. 
Rothman MD, Anderson RJ, Smit AJ (2006) The effects of harvesting of the South African kelp (Ecklonia maxima) on kelp population structure, growth rate and recruitment. Journal of Applied Phycology 18: 335-341.

Rueda FM, Martinez FJ, Zamora S, Kentouri M, Divanach P (1998) Effect of fasting and refeeding on growth and body composition of red porgy, Pagrus pagrus L. Aquaculture Research 29: 447-452.

Sales J (1999) Digestibility of feedstuffs in abalone (Haliotis species). AFMA MATRIX (Journal of the South African Feed Manufacturers Association) 8: 17-21.

Sales J, Britz PJ (2001) Research on abalone (Haliotis midae L.) cultivation in South Africa. Aquaculture Research 32: 863-874.

Sales J, Janssens GPJ (2004) Use of feed ingredients in artificial diets for abalone: a brief update. Nutrition Abstracts and Reviews: Series B74: 13N-21N.

Segawa S (1991) Oxygen consumption and ammonia excretion by the abalone Sulculus diversicolor aquatilis in starved condition. Nippon Suisan Gakkaishi 57: 2001-2006.

Simpson BJA, Cook PA (1998) Rotation diets: A method of improving growth of cultured abalone using natural diets. Journal of Shellfish Research 17 (3): 635-640.

Steinberg J (2005) The illicit abalone trade in South Africa. ISS Occasional Paper No. 105, pp. 11.

Takami H, Yamakawa H, Nakano H (1995) Survival and Physiological Stress of Juvenile Disk Abalone Haliotis discus discus during Long-Term Starvation. Fisheries Science 61 (1): 111-115.

Troell M, Robertson-Anderson D, Anderson R, Bolton J, Maneveldt G, Halling C, Probyn T (2006) Abalone farming in South Africa: An overview with perspectives on kelp resources, abalone feed, potential for on-farm seaweed production and socioeconomic importance. Aquaculture 257: 266-281.

Weatherly AH, Gill HS (1981) Recovery growth following periods of restricted ration and starvation in rainbow trout, Salmo gairdneri Richardson. Journal of Fish Biology 18: 195-208. 
Zhu W, Mai K, Wu G (2002) Thiamin requirement of juvenile abalone, Haliotis discus hannai Ino. Aquaculture 207: 331-343. 